\title{
The Influence of School Environment towards Primary School Students' Discipline
}

\author{
Rusmin Husain ${ }^{1}$, Lindawati ${ }^{2}$. \\ \{rusmin.husain@ung.ac.id ${ }^{1}$ \} \\ ${ }^{1,2}$ Department of Primary School Teacher Education, Universitas Negeri Gorontalo, Jl. Jendral \\ Sudirman No. 6 Gorontalo City, Postal Code 96128, Gorontalo Province, Indonesia
}

\begin{abstract}
This research aims to identify the influence of school environment towards primary school students' discipline. From the population a total of 170 primary school students of SDN 1 Telaga, Gorontalo regency, the study included 63 students as the sample of research. This study employed ex-post facto research design and regression and correlation analysis to test the research hypothesis. The result shows that school environment contributes to the primary school students' discipline. Furthermore, the research conducted statistic data processing and obtains correlation coefficient of $r=$ 0.74 , in other words, the variable of school environment plays a significant contribution to the students' discipline. Furthermore, the finding is echoed by determination value of 54.76 percents (from $\mathrm{r}^{2}=0.5476$ ). Therefore, this study argues that the environment of SDN 1 Telaga has 54.76 percent contribution towards the students' discipline
\end{abstract}

Keywords: School environment, students' discipline.

\section{Introduction}

In the perspective of education, there are three main environments whose contributions are significant to develop a child's personality, i.e. family, school, and the community. Discipline is considered as one of the foremost personalities of a child to be shaped as early as possible. It is a condition shaped through the development process of a set of behavioral value of obedience, loyalty, and orderliness. Moreover, it is believed that school environment plays the most significant role to shape a child's discipline. The school environment acts as a vessel to develop a child's discipline. Thus one can implement the values of discipline in the family and the community.

Discipline has been defined as a set of the behavior of an individual which portrays a sense of obedience, the awareness to accomplish duties, and obligations to achieve the objective [1]. On top of that, essentially, discipline is an organized action, to put it another way, discipline in performing task means that one accomplishes his or her task accordingly.

This is a contrast to the situation, in which from the observation in SDN 1 Telaga revealed that the students' performed poor actualization of discipline values. The students tended to come late, disobeyed the teacher's command, dressed inappropriately in the class and at the flag ceremony. The students also performed poor discipline during the learning 
process and confronted each other or between seniors and juniors. The situation was echoed by the teachers, parents, and the students themselves. The environment of SDN 1 Telaga is believed to play amajor role in the situation. The observation showed that the environment in the school was far from conducive; the students did not comprehend the school regulations, the lack of assertiveness on punishments to the discipline offender, and the inexistence of proper discipline role model in the school. Such a condition is worth investigating, considering that this phenomenon is quite common in the society.

\section{Literature Review}

\subsection{Students' discipline}

Students' discipline is a set of obligated rules for the students in a school. Salim [2] asserts that discipline is a portrayal of an ideal life in a community or a state.

\subsection{Indicators of students' discipline}

Gunarsa [3] emphasizes four indicators of discipline, i.e. punctuality, assertiveness, honesty, and responsibility.

\subsection{Contributing factors of students' discipline}

Ekosiswoyo and Rachman [1] assert that there are two contributing factors of students' discipline, i.e. school environment and family environment.

\subsection{Components of school environment}

Karwati and Priansa [4] mention three important components of a school environment, i.e. physical environment, non-physical/social environment, and academic environment.

\section{Research Method}

This study employed quantitative approach by ex-post facto design. Gay (in Emzir, 2007, p.119) states that ex-post facto design is a model of research in which the researcher tries to identify reasons for any differences in behavior or status in a particular group [5]. Furthermore, Sugiyono [6] claims that ex-post facto research is conducted to analyze an event by tracking back to the contributing factors of the event. Ex post facto design shares several resemblances with experimental studies; however, there is no treatment of free variable in $e x$ post facto design. This research engages the design to identify the influence of environment of SDN 1 Telaga towards the students' discipline. To obtain the sample from all students in SDN 1 Telaga, the research carries out probability sampling by stratified random sampling model. The sampling model was conducted within a group with levels or grades, such as school. The study included the sample of 63 students from the third grade until the sixth grade since the students in the grade have adequate capability to process and comprehend the researcher's statements.

\section{Discussion}

A statistical test is essential to conduct based on the problem statement and research hypothesis: "The environment of SDN 1 Telaga influences the students' discipline". The research engaged normality test on the data and found out that the result of $\mathrm{X}$ (school 
environment) and Y variable (students' discipline) was abnormally distributed. Furthermore, the research conducted hypothesis test by regression and correlation analysis resulted in regression equation value of $\hat{\mathrm{Y}}=\mathrm{a}+\mathrm{bX}$ or $\hat{\mathrm{Y}}=39.87+0.23 \mathrm{X}$. It is elaborated from the equation that when a unit of the variable of school environment changes, it is followed by an average of 0.23 of students' discipline variable. On top of that, the analysis result showed that the value of linearity and significance of correlation coefficient were linear.

Furthermore, based on the statistical test, the research obtained correlation coefficient value of $r=0.74$ which means that the school environment variable contributes significantly to the students' discipline. Also, the result was supported by determination coefficient value of $\mathrm{r}^{2}$ $=0.5476$ or $54.76 \%$. In the completion, this study referred to Awalludin (2001, p.3-15) [7].

From the equation of linear regression result of both variables, the results indicate that the indicators of school environment i.e. physical condition (facility and infrastructure), social environment (relationship between students, between students and teachers, and between students and school staffs), and academic environment (school atmosphere, learning process, and regulations) is said to influence the students' discipline significantly.

Furthermore, the correlation coefficient and determination coefficient value shows that the environment in SDN 1 Telaga contributes 54.76 percents to the students' discipline, while the rest $45.24 \%$ was elaborated by other variables. The variables of the investigation are the teachers, curriculum, teaching method, and school regulations. On top of that, by the observation conducted, the study discovered that most of the discipline offenders were influenced by their friends or by external factors from outside the school.

Ultimately, it is deduced from the result that the environment of SDN 1 Telaga plays a significant role in the students' discipline. It is essential for the school to have role models of discipline to enhance the students' discipline.

\section{Conclusion and Recommendations}

By the analysis result, the research concludes that the environment of SDN 1 Telaga contributes significantly to the students' discipline by the result of 0.74 or 54.76 percents. Furthermore, the research proposes several recommendations for:

1. The teachers

The study recommends the teachers to be more observant of the students' discipline and be arole model for the students. Therefore, the teachers are expected to perform proper time management, to be more assertive, and to actualize values of honesty and responsibility, since the students are more likely to imitate that to discover things by themselves.

2. The students

The research expects that the students actualize the values of discipline and comprehend of the regulations in the school

3. The further researchers

This study acts as a reference to the significance of school environment towards the students' discipline. Furthermore, the further researchers are expected to broaden the scope of research subject to other schools. 


\section{References}

[1] Ekosiswoyo \& Rachman. (2000). Bimbingan Kearah Belajar Yang Sukses. Surabaya: Akasara Baru.

[2] Salim, MohamadHaitami. 2013. Pendidikan Karakter. Yogyakarta: Ar-Ruzz Media

[3] Gunarsa, Ny. Singgih D dan Gunarsa, Singgih D. 2007. Psikologi untuk melakukan bimbingan. Jakarta: Gunung Mulia

[4] Karwati, Euis, dan Donni Joni Priansa. 2014. Manajemen Kelas (Classroom Management) Guru Profesional yang Inspiratif, Kreatif, Menyenangkan, dan Berprestasi. Bandung: Alfabeta.

[5] Emzir. 2007. Metodologi PenelitianPendidikan. Jakarta: Rajawali Pers

[6] Sugiyono, 2015. Metodologi Penelitian PendidikanPendekatan Kuantitatif, Kualitatif, dan $R \& D$. Bandung:Alpabeta

[7] Awalludin. 2009. Statistika Pendidikan.Direktorat Jendral Pendidikan Tinggi Departeman Pendidikan Nasinal 